\title{
DISMANTLING AND RECONSTITUTION OF PRASAT SUOR PRAT, ANGKOR THOM, CAMBODIA
} \author{
Koichi Nakagawa ${ }^{5}$, Ichita Shimoda ${ }^{6}$, Takeshi Nakagawa ${ }^{7}$ \\ Geo research Institute; Kokumin-Kaikan, 6FI, 2-1-2 \\ Ohtemae, Chuo-ku, Osaka, 540-0008, Japan \\ yoshi-iw@geor.or.jp \\ Taisei Geo-Tech Co. Ltd. Kumamoto, Japan \\ ${ }_{3}^{2}$ Japan Cultural Heritage Consultancy Co., Tokyo, Japan \\ ${ }_{4}$ Tokyo Engineering Consultants Co. Ltd. Tokyo, Japan \\ ${ }_{5}^{4}$ Osaka City University. \\ ${ }_{6}^{5}$ Tsukuba University, Tsukuba, Japan \\ ${ }_{7}$ Waseda University, Tokyo, Japan
}

Yoshinori Iwasaki', Mitsuharu Fukuda², Yasushi Akazawa³ ${ }^{3}$ Junichi Nakazawa ${ }^{4}$,

\begin{abstract}
This paper presents a geotechnical aspects of dismantling process of one of masonry towers named Prasat Suor Prat that had been constructed in the end of $12^{\text {th }}$ century during the Angkor Period in Cambodia. A series of 12 towers had been constructed from south to north along the east side of Royal Plaza in Angkor Thom.

One of the towers, named as N1 Tower, was found badly displaced with inclination of about 5 degrees to the north-west and horizontal spreading at the foundation level. The Tower was dismantled before restoration work by JSA (Japanese Government Team for Safeguarding Angkor) to study possible mechanism that had caused inclination of the Tower and horizontal spreading of stair stones. Dismantling upper structures as well as foundation mound were performed by archaeological trench. The trench had revealed the mechanism of deformation of the structure as well as foundation. Before the dismantling, was the inclination caused by tilting of the foundation mound caused by general sliding failure of the foundation towards adjacent pond. However, it was revealed that the mound was not tilted but kept horizontal under yielded state causing only horizontal spreading. It was found the inclination was caused by slip down of the sidestep cut stones that had covered the side slopes of the mound
\end{abstract}

\section{Keywords:}

Prasat Suor Prat, Angkor, dismantling of heritage structure, inclination, foundation spreading

\section{Introduction}

Angkor locates at a wide plain that expands between the Kulen Mountain in the north and the Ton le Sap Lake in the south as shown in Fig.1.The width of the plain is about $50 \mathrm{~km}$ with gentle inclination of $1 / 1000$ from the north to south.

Angkor monuments distribute within the vast area of the plain. The famous monuments of Angkor Wat as well as Angkor Thom locate in the middle of the plain. Water is provided in the plain not only from rain fall but also from Kulen Mountain by Siem Reap River. In the middle of the plain, great man made reservoirs called as "Barai" were constructed to supply water in dry season. At present the West Barai is still in use with a dimension of $8 \mathrm{~km}$ by $2.5 \mathrm{~km}$ as shown in Fig.1.
JSA (Japanese Government Team for Safeguarding Angkor) had performed the first deep geological boring in the area that revealed underground condition in 1994.

Fig. 3 shows a north-south section of the boring logs at the Royal Plaza, Bayon in Angkor Thom, Angkor Wat, and Siem Reap city. The upper $40 \mathrm{~m}$ of the ground surface is Quaternary deposits of silty fine sand with several clayey rich layers. In general SPT (standard penetration Test) $\mathrm{N}$-value increases with depth except at the top surface. $\mathrm{N}$-value at the top surface is 20 and decreases to 10 at the depth of $5 \mathrm{~m}$. The boring at this point was carried out in March 1995 of dry season. The cone penetration test that was performed in rainy season at the same site revealed that the cone resistance decreased to 


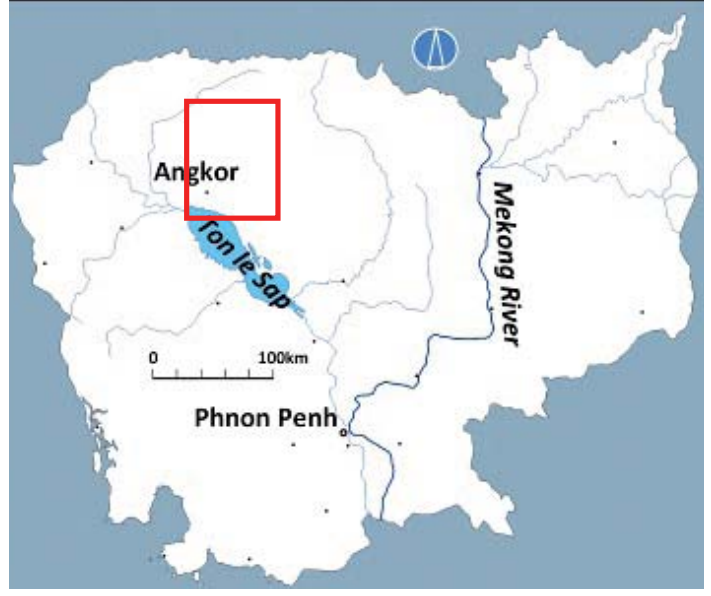

Fig.1. Cambodia and Angkor

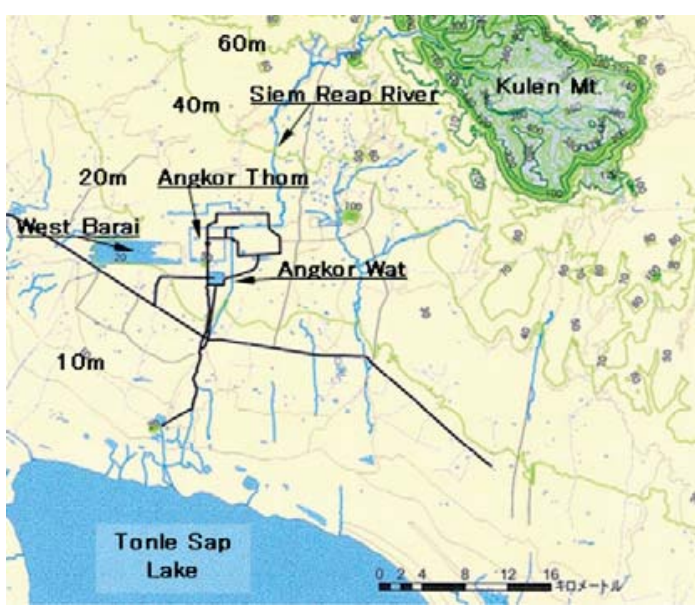

Fig.2. Angkor area (see the quadrangle area in Fig.1)

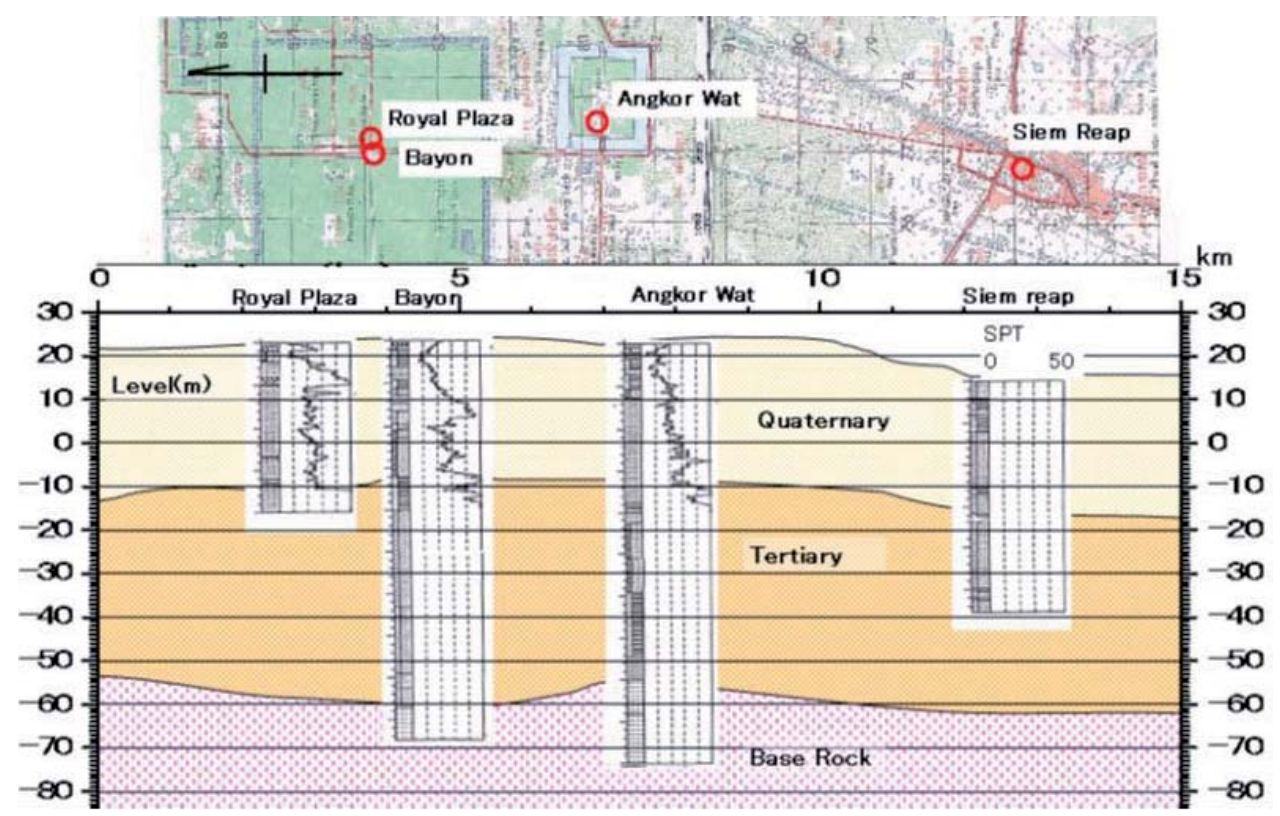

Fig.3. Geotechnical Section along N-S section from Bayon, Angkor Wat, to SiemReap

zero at the surface and increased with depth down to about $5 \mathrm{~m}$. The top surface of $5 \mathrm{~m}$ is affected by the seasonal change of water level.

Water condition in the ground gives crucial effects upon mechanical characteristics of surface ground in Angkor and forms one of the characteristic elements of cultural heritage.

\section{Prasat Suor Prat}

Prasat Suor Prat (Tower of Rope Dancer) is a group of 12 independent towers along the west side in the Royal Plaza as shown in Photo-1 and in Fig.4 of plan view. These towers are divided into two groups of North and South. The inclination of side walls for all the towers at Prasat Suor Prat were measured and listed in Table1 and shown in Fig.5. Inclinations of the towers are less than 2-4 degrees exept $\mathrm{N} 1$ and $\mathrm{S} 1$ and with direction of NW to NE. $\mathrm{N} 1$ and $\mathrm{S} 1$ show the largest inclination among each group. Each Tower stands near the north and the south ponds respectively (Akazawa, 2005).

The largest inclination was found for N1Tower. The following section was devoted to the state of deformation before conservation of 2000-2005.

\section{Deformation characteristics of $\mathrm{N} 1$ Tower}

One of the 12 towers named as $\mathrm{N} 1$ that had been inclined about 5 degrees northwards was selected by JSA for safeguarding work as shown in Photo 2. The tower consists from a main tower with a front room called antechamber. The main tower is three story masonry structure with laterite brocks with $10 \mathrm{~m}$ in width at foundation and about $20 \mathrm{~m}$ in height. The inside of the tower is hollow structure with four open windows at every wall. Fig.6 shows vertical section and plan view of the N1 tower nearby the north pond.

The differential settlement of the foundation was measured about $40 \mathrm{~cm}$ at the north and west corner 


\section{Architecture and Engineering Volume 1 Issue 1}

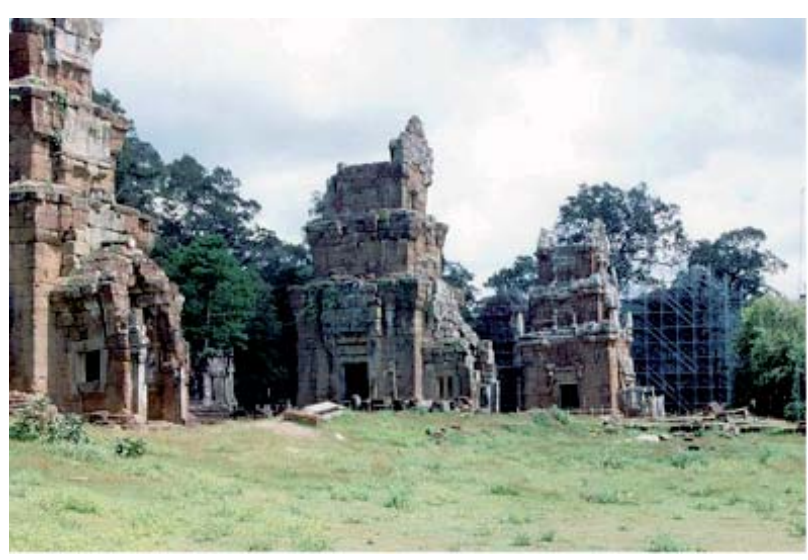

Photo 1. Prasat Suor

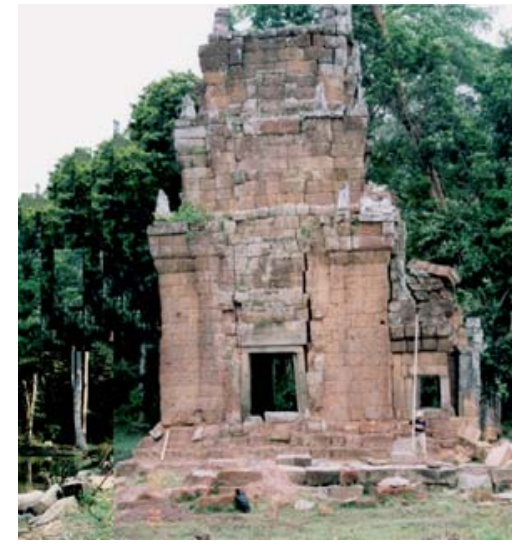

Photo 2. N1 Tower, Prasat Suor Prat

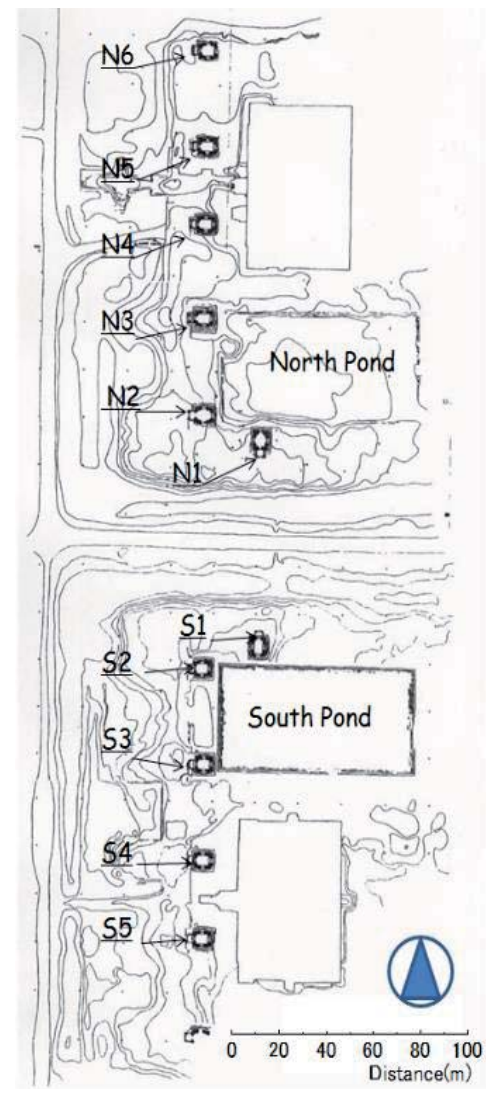

Fig.4. 12 towers of Prasat Suor Prat
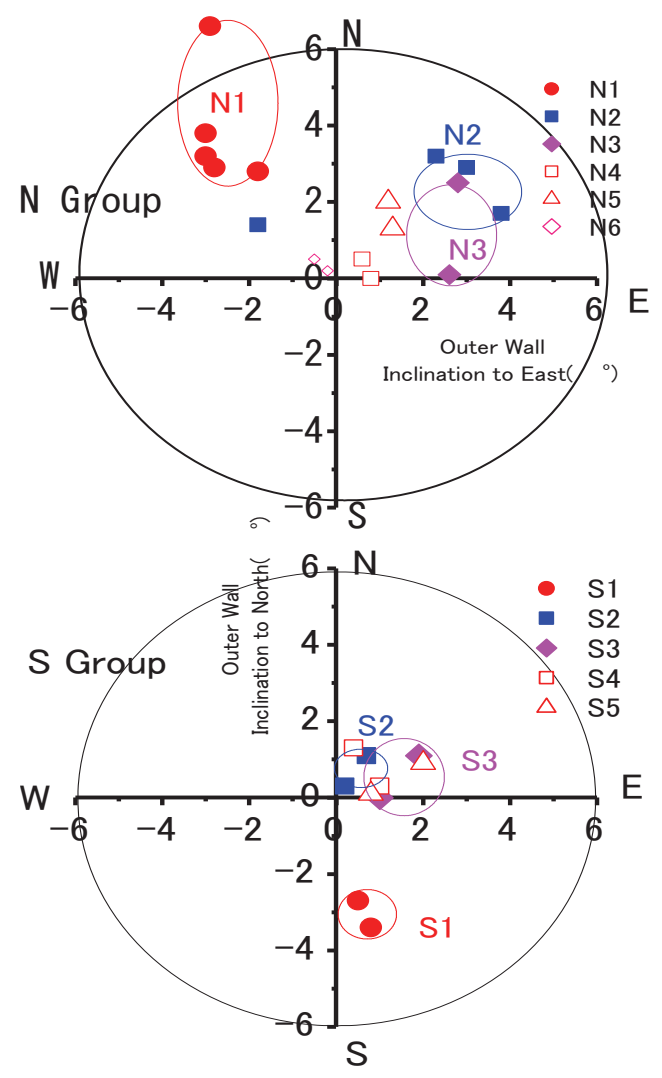

Fig.5. Inclination of Towers that was lower than that of the south and east corner (Akazawa, 2005 and Fukuda, 2005).

Fig.7 also shows contour lines of equi-settlement relative to the south-east corner of the foundation.

The open window of the west wall is deformed as shown in Photo 3.

The widths of the bottom of the window are wider than those of the top for all four walls and the measured results are shown in Table-1. The laterite blocks of the side face of the foundation were found widened about $6-8 \%$. One of the characteristics of the deformation of the foundation of $\mathrm{N} 1$ Tower is horizontal spreading. Fig. 8 shows two major trends of deformation in the foundation system of inclination towards the North pond and horizontal spreading.

Table 1

Inclination of side walls at Prasat Suor Prat

\begin{tabular}{|c|c|c|c|c|c|c|}
\hline Group & No.1 & No.2 & No.3 & No.4 & No.5 & No.6 \\
\hline North & 3-7 NNW & 3-4 NE & $2-4 \mathrm{NE}$ & $0-1 \mathrm{NE}$ & $0-1 \mathrm{NW}$ & $0-1 \mathrm{NW}$ \\
\hline South & $3-4 \mathrm{SSE}$ & $0-2 \mathrm{NE}$ & $1-3 \mathrm{NE}$ & $1-2 \mathrm{NE}$ & $2-3 \mathrm{NE}$ & \\
\hline
\end{tabular}


Table 2

Width of open window at top and bottom

\begin{tabular}{ccccc}
\hline Side & \multicolumn{2}{c}{ Width of opening } & Difference & $\begin{array}{c}\text { Expanded } \\
\text { rate }\end{array}$ \\
\hline & top & bottom & & \\
\hline & $\mathrm{Lt}$ & $\mathrm{Lb}$ & $\Delta \mathrm{L}=\mathrm{Lb}-\mathrm{Lt}$ & $\Delta \mathrm{L} / \mathrm{Lt}$ \\
\hline east & $\mathrm{cm}$ & $\mathrm{cm}$ & $\mathrm{cm}$ & $(\%)$ \\
west & 170.3 & 182.0 & 12.0 & 7.1 \\
north & 168.0 & 185.0 & 14.0 & 8.2 \\
south & 124.0 & 131.7 & 7.7 & 6.0 \\
& & & & 6.2
\end{tabular}

The horizontal line of side face stones of foundation mound was inclined to northwards. The levels of upper surface of the top (L1), the second (L2), and the third (L3) lines in the upper part of Fig.7 were measured at several points and plotted in the lower part of Fig.7. The inclinations of these side stones of the foundation mound were found about $0.4 \mathrm{~m}$ per $10 \mathrm{~m}$ of horizontal distance. The inclination of the foundation as well as upper structure suggested that the inclination of the Tower might have been caused by such ground deformation as sliding failure.

\section{Dismantling of Heritage Structure}

It is generally accepted that dismantling should be avoided if other method is available for restoration work. The ICOMOS Charter - Principles for the Analysis, Conservation, and Structural Restoration states 3.17 Dismantling and reassembly should be undertaken as an optional measure required by the very nature of the material and structure when conservation by other means impossible or harmful.

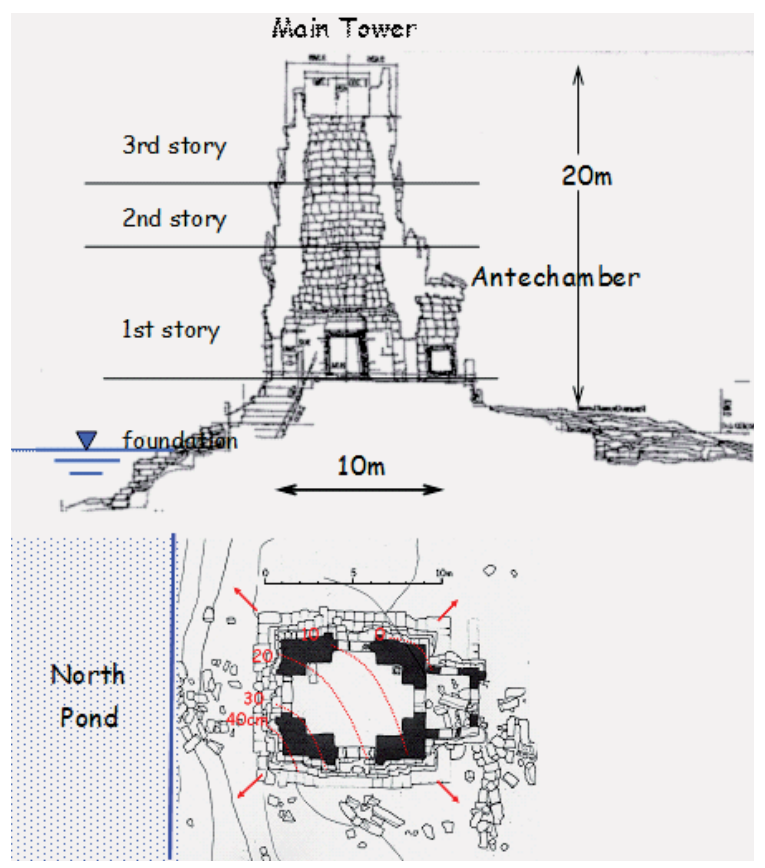

Fig.6 Vertical section and plan for N1 Tower

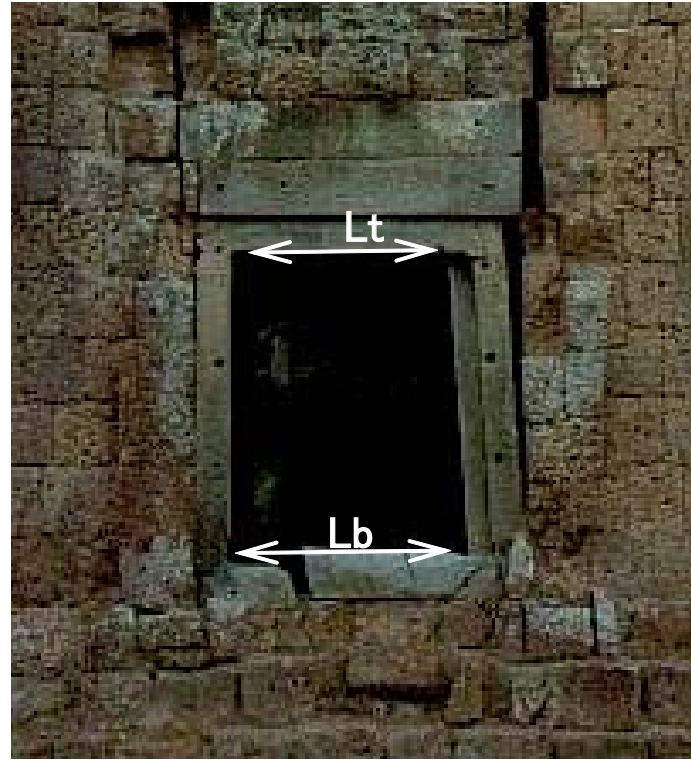

Photo 3. Deformed frame of open window at west side

Restoration work of N3 Tower in 1960 and Dismantling N1 Tower

In 1960,' N3 Tower of Prasat Suor Prat had been found badly inclined. French team had performed restoration work for the N3 Tower. Stones of the upper structure had been dismantled without treating the foundation system. After the restoration work, the N3 Tower had been found inclined again within a few years. When JSA began the restoration work of N1 Tower of Prasat Suor Prat, the question of insufficient result of restoration work of N3 was discussed.

As shown in the previous section, the foundation of the N1 Tower had been inclined to NNW direction
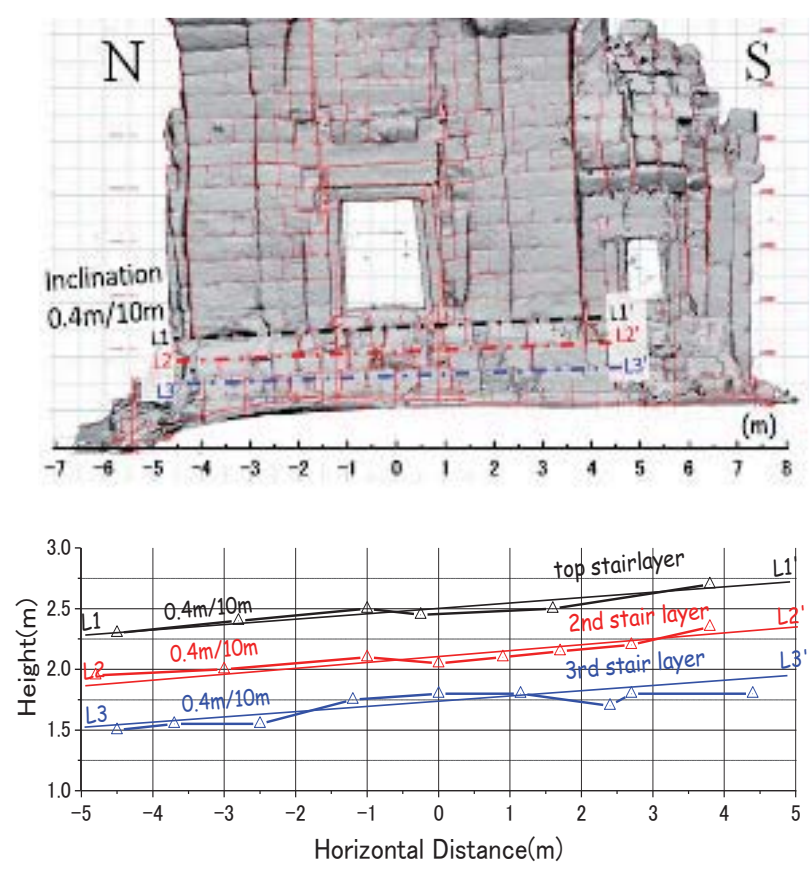

Fig.7 Inclination of step stones at the west side, N1 Tower 
and spread horizontally in all directions. It was clear that the deformation of upper structure had been caused by insufficient performance of the foundation system. It was decided to study foundation system by dismantling and solve mechanical instability that had caused inclination and spreading of the upper structures.

\section{Dismantling of N1 Tower}

Dismantling of N1 Tower of Prasat Suor Prat was carried out before reconstruction of the Tower.

After the laterite blocks of the upper structure were dismantled, the foundation structures were further dismantled. The soil mound was excavated down to reach natural ground layer (Nagatomo et al., 2005).

Photo 4 shows the trenched site of N1 Tower of Prasat Suor Prat, where vertical section was exposed.

Fig.8 shows a trenched section of N1 Tower along N-S direction. The upper structures consist

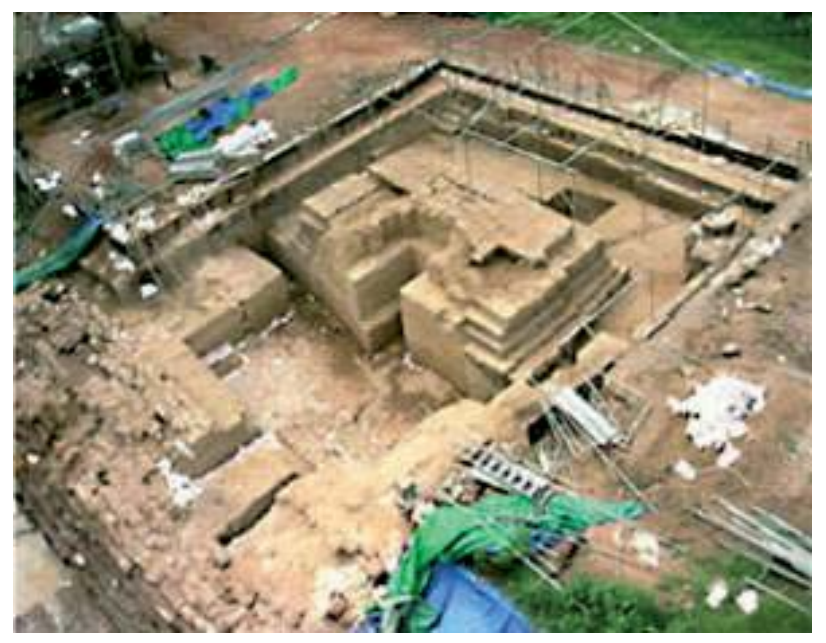

Photo 4. Archaeological trench at N1 from Main Tower and Antechamber. The bottom level of the upper structures was the same level of top level of side step stones. As already stated, the top level of step stones had inclined to northwards with settlement of $0.4 \mathrm{~m}$ for horizontal length of $10 \mathrm{~m}$ as shown in Fig.7 and also indicated in Fig.8 as well.

When the trench proceeded to the level of $+0.00 \mathrm{~m}$, the manmade compacted sand layers were exposed. We had expected the same inclination of the compacted soil layers in the foundation mound. However, amazingly, we found the manmade layers of soil mound formed almost horizontal layers as shown in Fig.8. It was mysterious for us to understand until the excavation reached to the much lower level.

\section{Deformation mode of foundation failure}

When the trench was further deepened, the section in the north side of the foundation mound showed a small local bearing failure at horizontal point Y11 in Fig.8, which had resulted in sliding of retaining slope of north side face. The bottom element of side stones had settled by about

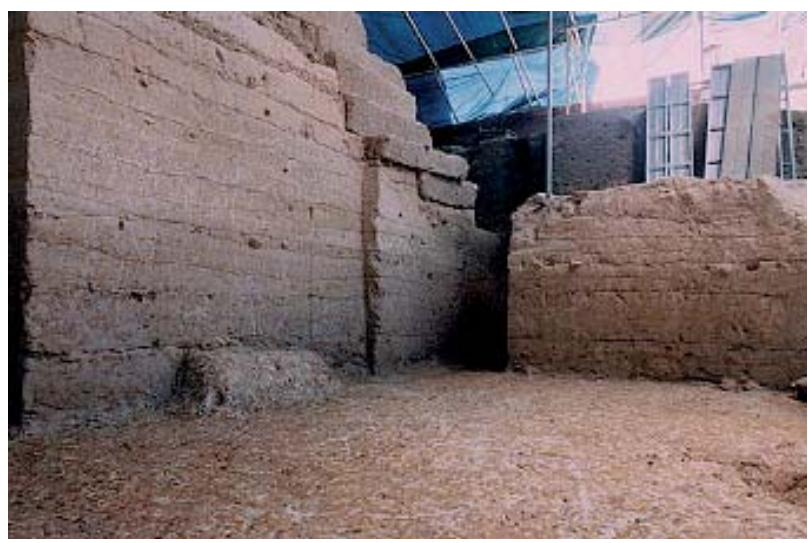

Photo 5. Trenched EW section (note the horizontal layers)

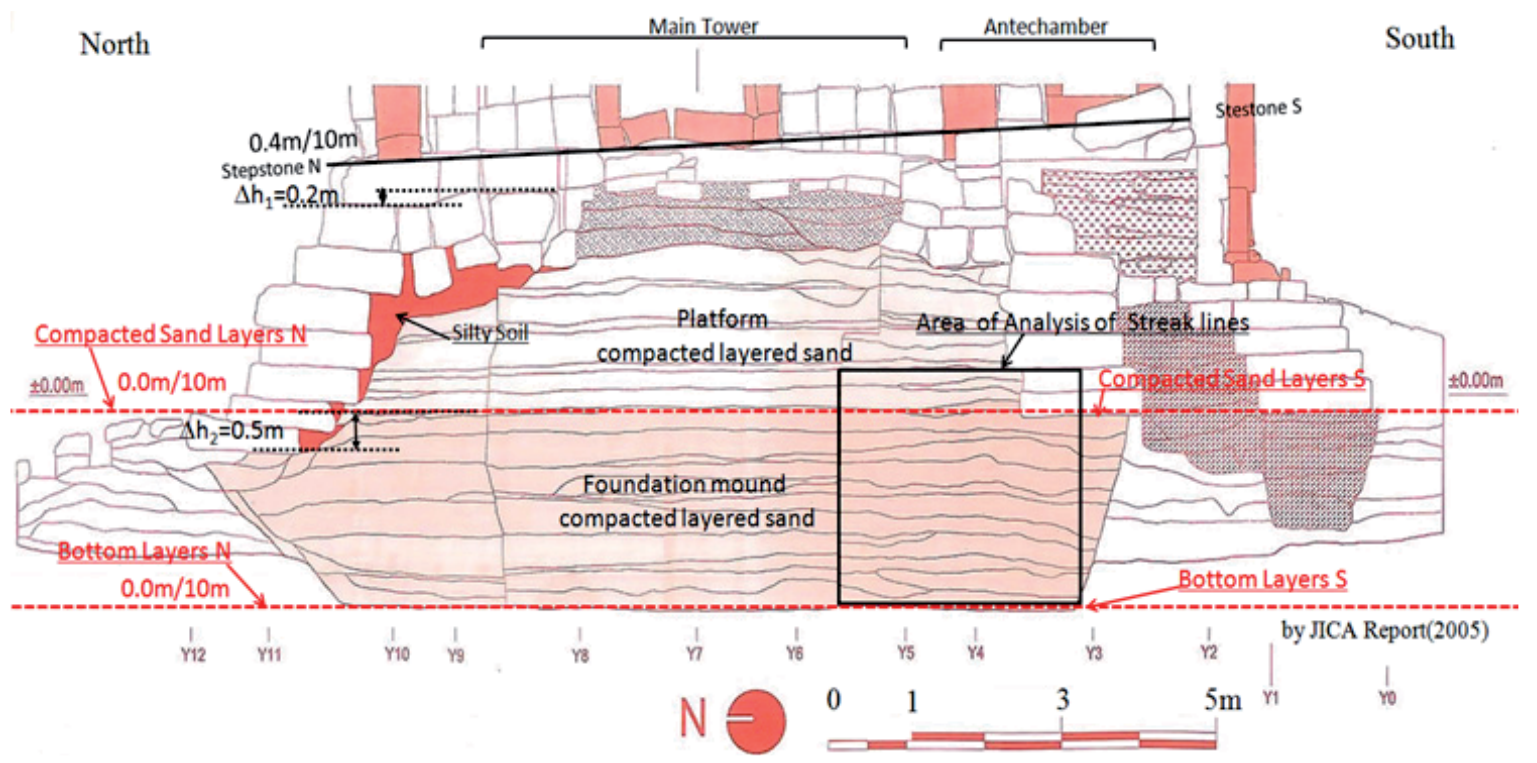

Fig.8. Trenched section along N-S direction 


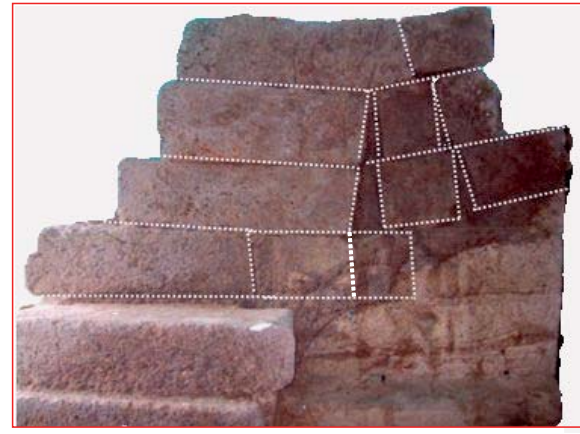

Photo 6. Side stone at north face

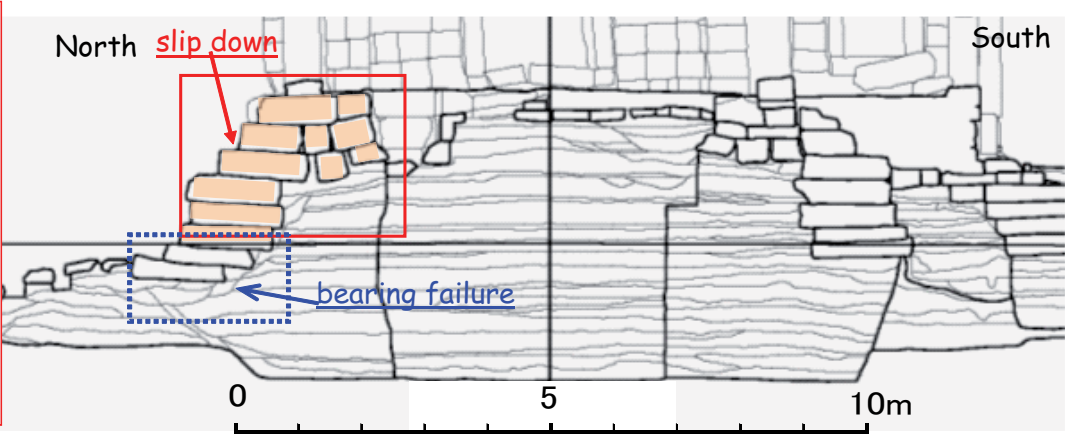

Fig.9. Mode of failure of step stones at the north side
$\Delta \mathrm{H}_{2}=0.5 \mathrm{~m}$ from the original level. The bearing failure took place for the bottom of the step stones. It should be noticed that the bottom of the step stones settled about $0.5 \mathrm{~m}$, however, the highest block of the step stones was found settled only $\Delta \mathrm{H}_{1}=0.2 \mathrm{~m}$ as shown in Fig. 8 .

It is estimated that the bearing failure at the base had been the initial step of the failure that caused to drag the upper step stones to slip down as shown in Fig.9.

Photo 6 shows the deformation of step stones at north side. The outer most stone settled and displaced outwards. Accordingly, the side stones behind the front stones were also displaced outwards but the horizontal displacement was less than the front stones.

\section{Systematic streak line on the trenched} surface

As shown in Photo 7 and in Fig.10, many streak lines were found on the face of trenched section of platform and foundation mound. Based upon the photos of the sections, the streaks were analyzed in the part of squired section of "Area of Analysis of Streak lines" shown in Fig.8.

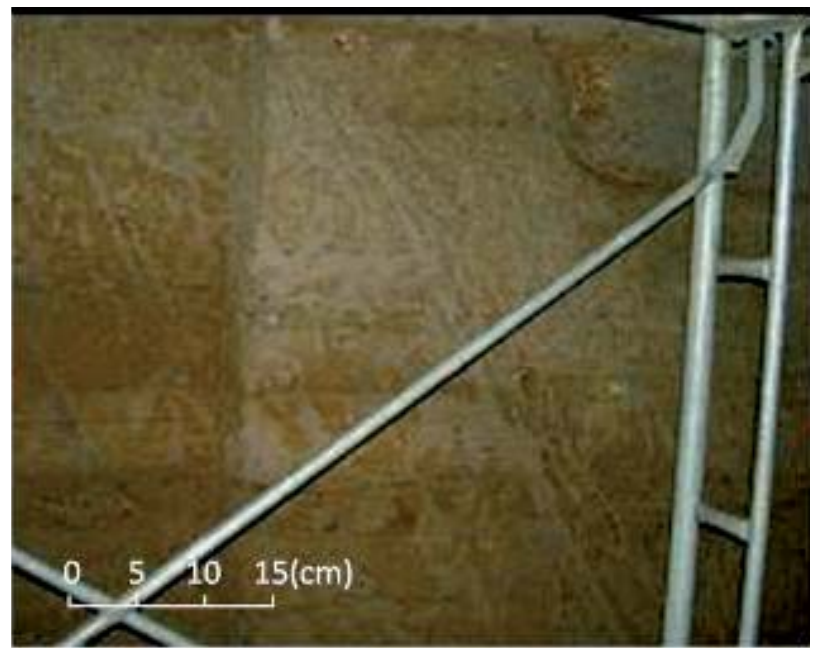

Photo 7. Streak lines on the trenched surface
The area shown in Fig.8 was further divided into two sections of upper and lower part as shown in Fig. 11 and the distribution of the angle of streak lines were analyzed and the distribution patterns of the angles of streak line from the vertical line are plotted in Fig.12. The strong tendency of the angle of 30 degrees from the vertical direction was obtained, which suggests the streak lines correspond to shear surface under failure.

The angle between the direction of failure surface and principal stress direction under the MohrCoulomb in

$$
\theta=45 \pm \phi / 2 \quad \text { (equation-1) }
$$

where

$\theta$ : angle between shear plane and principal major stress axis

$\phi$ : internal angle of friction of material.

Since the internal frictional angle of sand obtained by laboratory test was 30 degrees, $\theta$ become 30 degrees when the vertical overburden stress is the major principal stress.The appearance of these streak lines suggests that the foundation mound might have experienced plastic yielding under vertical load.

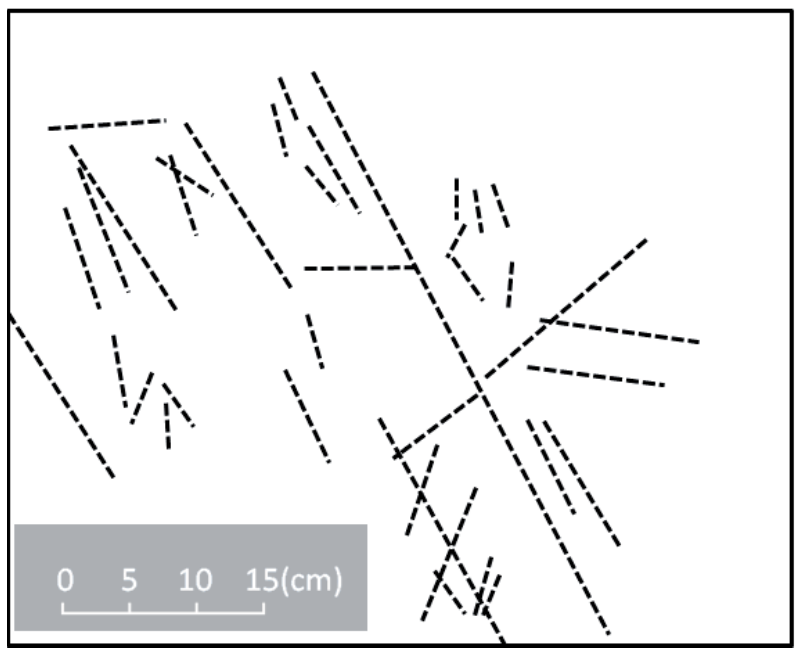

Fig. 10. Sketch of streak line on trench surface of Photo 7 


\section{Distribution of Cracks on the Trench Wall}
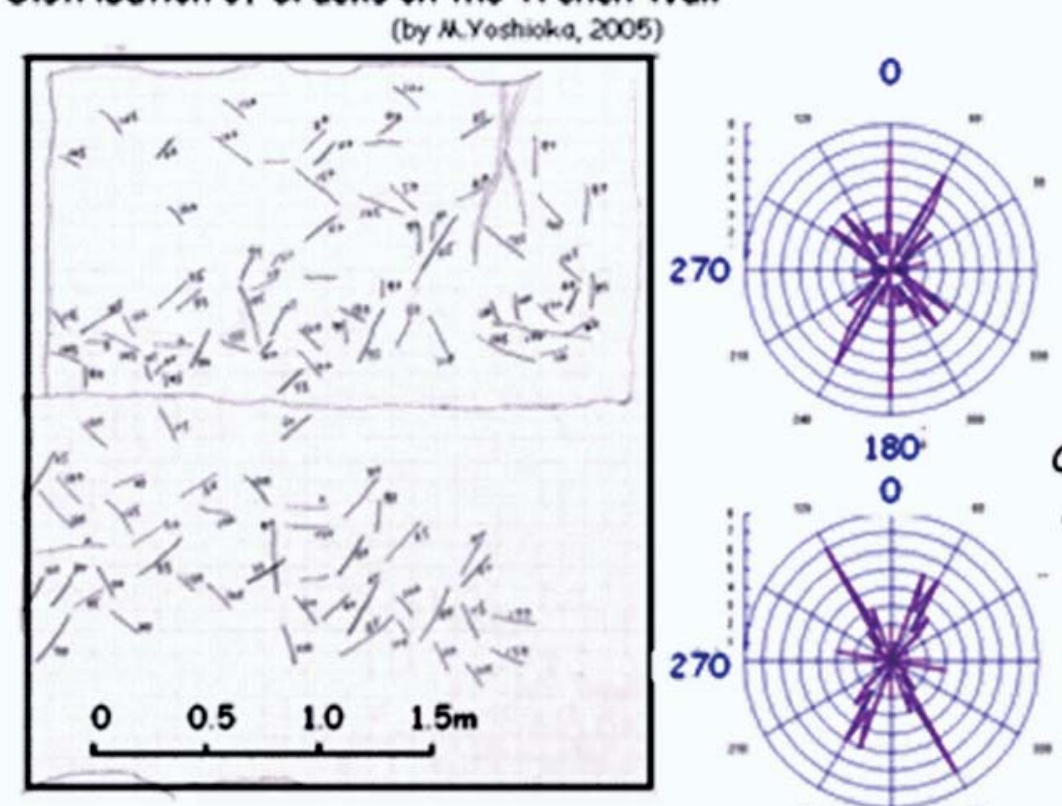

90

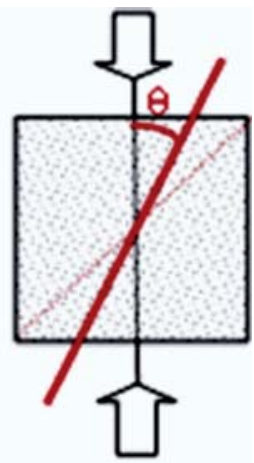

Fig.11. Sketch of streak lines in the section shown in Fig.8

Fig.12. Distribution of angles of streak lines

\section{Distribution of}

Crack Angles for

every 5 degrees

\section{0}

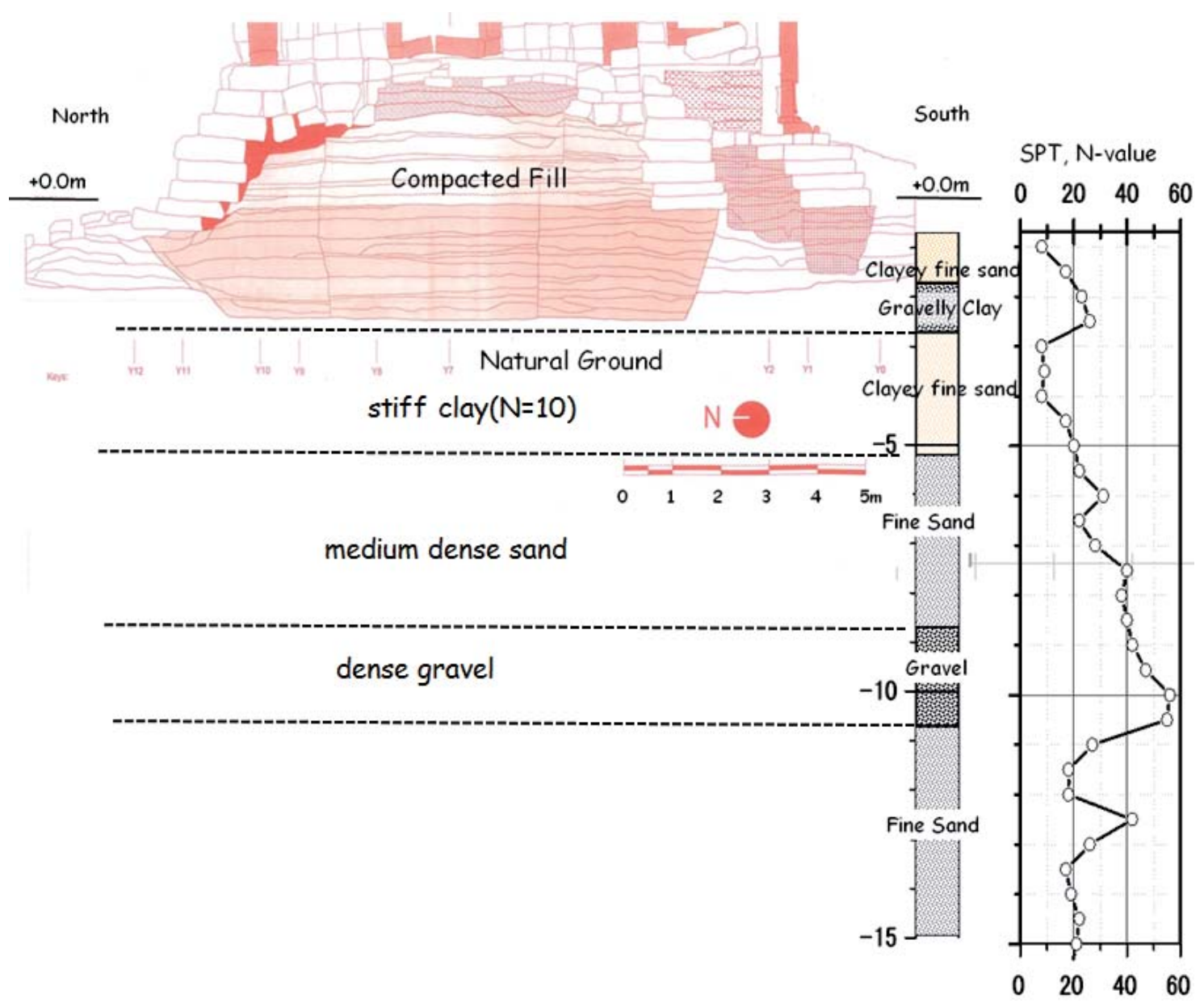

Fig.13. Geotechnical Condition near N1 Tower, Prasat Suor Prat 


\section{FEM Simulation of yielding of foundation soil of N1 Tower, Prasat Suor Prat}

The response of the compacted soil mound by loading of the upper structure is simulated by a FEM and the result of the distribution of yielding points shall be shown.

Geotechnical condition at the site is shown in Fig.13. Beneath the compacted sand mound, stiff clay $(\mathrm{N}=10)$ of natural formation follows some $3 \mathrm{~m}$. There are medium to dense sand and gravel layers below the stiff clay.

Material Parameters are assigned based upon triaxial test results and field plate loading tests for compacted sand mounds and estimated parameters for laterite and natural soils as yielding condition of Mohr-Coulomb criteria.

The estimated total weight of the upper masonry stone structure was $8.97 \mathrm{MN}$ which resulted in the vertical load of $421 \mathrm{kPa}$ at the top of the foundation. The maximum vertical settlement of $18.4 \mathrm{~cm}$ was obtained at the surface level of the mound. Figs.15 and 16 shows the distribution of plastic zones and shear strain that were caused by the load from the upper masonry structure of $400 \mathrm{kPa}$. Plastic zones were shown in Photo-5, many streak lines were found on the trenched section of platform and foundation mound. Based upon the photos of the sections, the streaks were analyzed in the part of squired section of "Area of Analysis of Streak lines" shown in Fig.8.

The area shown in Fig. 8 was further divided into two sections of upper and lower part as shown in Fig. 11 and the distribution of the angle of streak lines were analyzed and the distribution patterns of the angles of streak line from the vertical line are plotted in Fig.12. The strong tendency of the angle of 30 degrees from the vertical direction was obtained, which suggests the streak lines correspond to shear surface under failure.

The soil parameters are based upon some typical number estimated by the authors. However, the FEM results suggest the essential features of the characteristics of deformation of the Tower.

The seasonal change of level of underground water might have affected the strength of the soil mound and repeated nature of weakening soil mound has caused yielding of the mound and the

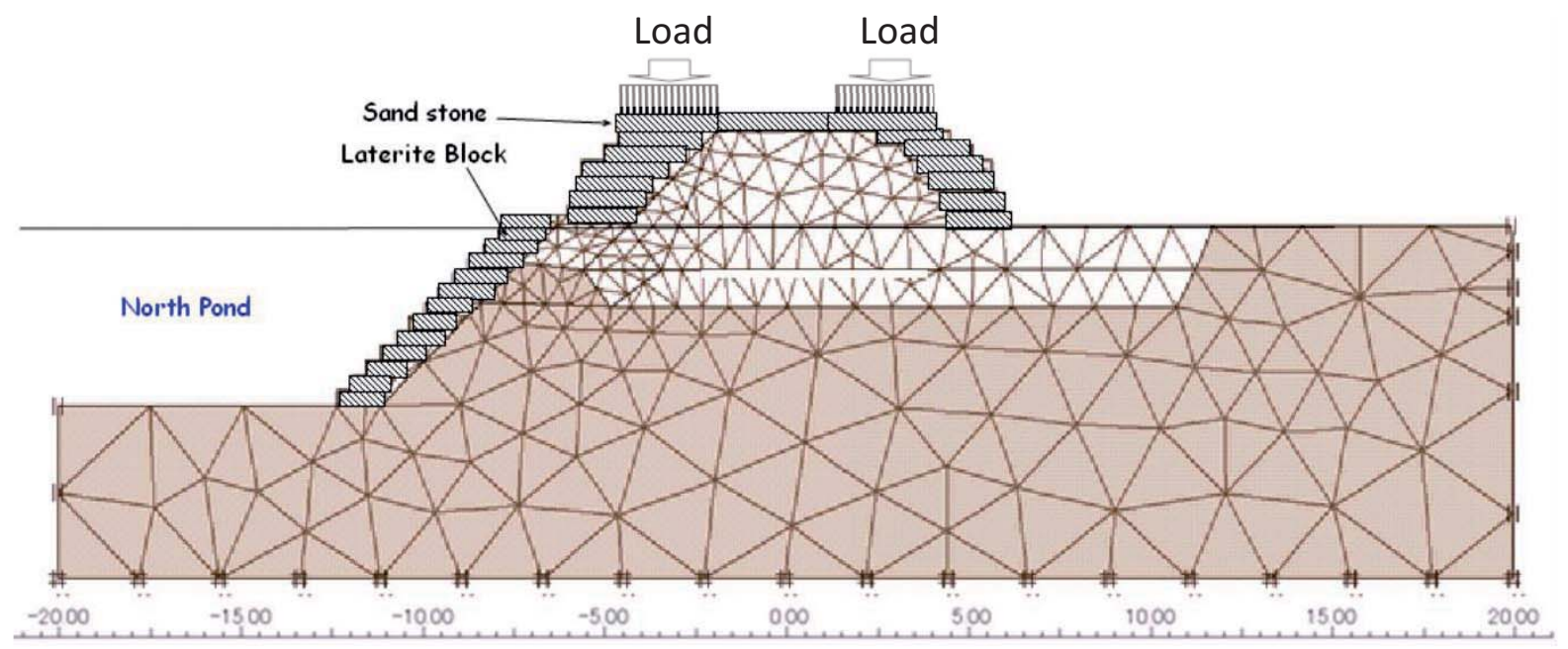

Fig.14. FEM mesh by PLAXIS 2D

Table 3

Soil parameters for FEM simulation

\begin{tabular}{|l|r|r|r|r|r|}
\hline Material & \multicolumn{1}{|l|}{ Young's Modulus } & Poisson's ratio & cohesion & Internal friction & Unit weight \\
\hline & $\mathrm{kPa}$ & & $\mathrm{kPa}$ & & $\mathrm{kN} / \mathrm{m} 3$ \\
\hline Compacted Soil & 25,000 & 0.3 & 25 & 30 & 18 \\
\hline Natural Soil & 10,000 & 0.3 & 20 & 30 & 18 \\
\hline Laterite/Sand stone & $1,000,000$ & 0.2 & & & \\
\hline
\end{tabular}

Table 4

Load from upper structure

\begin{tabular}{|c|c|}
\hline Load from upper masonry & \\
\hline Total weight & $8.97 \mathrm{MN}(879 \mathrm{tf})$ \\
\hline Load stress upon the foundation stone & $421 \mathrm{kPa}(43 \mathrm{t} / \mathrm{m} 2)$ \\
\hline The maxium settlement obtained at top of mound & $18.4 \mathrm{~cm}$ \\
\hline
\end{tabular}




\section{Architecture and Engineering Volume 1 Issue 1}

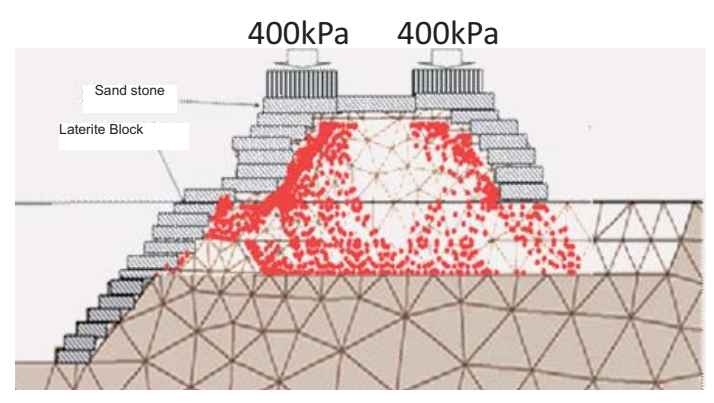

Fig.15. Plastic zone for loading of 400kP

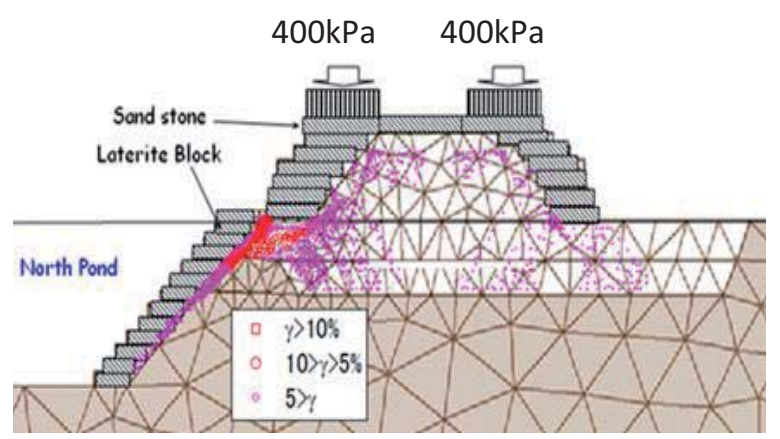

Fig.16. Shear strain for loading of $400 \mathrm{kPa}$

local base failure. The reconstitution process was reported by Akazawa $(2005, b)$.

\section{Conclusions}

The conclusions of this paper are listed as follows,

1. N1 Tower of Prasat Suor Prat, Angkor Thom, was dismantled to study deformation mechanism that had caused lateral spreading of the foundation and inclination of the Tower.

2. The N1 Tower shows inclination of about 5 degrees of the side walls of the tower and $0.4 \mathrm{~m}$

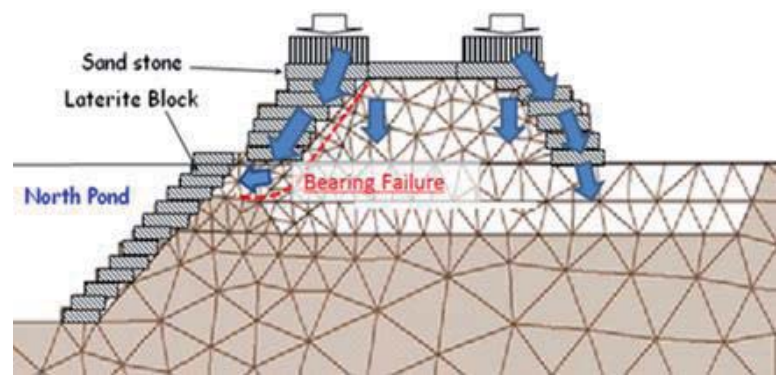

Fig.17. Stress flow in the foundation

settlement along the base step line of $10 \mathrm{~m}$. The horizontal spreading $6-8 \%$ at the base level. Before trenching work, the N1 Tower had inclined because of the general sliding of the foundation mound towards a nearby pond.

3. Archaeological trench was performed during dismantling and showed streak lines on the trenched surface that suggest yielding state of the soil mound under the heavy load of the upper structure.

4. The trench also showed horizontal layer of the soil mound that had nothing to do with the inclination of the upper N1 Tower, except a local failure at the base of side. The load of upper Masonry structure was supported by foundation stones that were further transmitted to side stones. Rather high intensity of loading stress concentrated beneath the bottom level of sidestone had failed and triggered slip down of the side step stones along the sideslope of the mound.

5. The dismantling was successful to disclose the geotechnical mechanism of the deformation of the foundation structure of N1 Tower, Prasat Suor Prat.

\section{References}

Akazawa,Y.(2005)"Damage Conditions before Repair and Modifications in later Years", Report on the Conservation and Restoration Work of Prasat Suor Prat Tower, 44-57, Tokyo, JSA

Akazawa,Y.(2005b)"Reconstruction of the Foundation and Platform","Report on the Conservation and Restoration Work of Prasat Suor Prat Tower, 269-298, Tokyo, JSA

Nagatomo,T.,Kong,V. and HENG, P.(2005)"Archaeological Surveys", Report on the Conservation and Restoration Work of Prasat Suor Prat Tower, 58-120, Tokyo, JSA

Fukuda,M.(2005),"Geotechnology, Geology, and Environment", Report on the Conservation and Restoration Work of Prasat Suor Prat Tower, 127-155, Tokyo, JSA 